\title{
PERSEPSI PENGUNJUNG TERHADAP KUALITAS REST AREA TAMAN GISTING SEBAGAI RUANG PUBLIK
}

\author{
Ferri Anggara Ade Gunawan ${ }^{1}$, Indah Listiana ${ }^{2}$, Yudha Rahman ${ }^{3}$ \\ ${ }^{1}$ Institut Teknologi Sumatera, Jl. Terusan Ryacudu Jati Agung, Lampung Selatan \\ ${ }^{2}$ Universitas Lampung, Jl. Soemantri Brojonegoro No.1 Rajabasa, Bandar Lampung \\ ${ }^{3}$ Institut Teknologi Sumatera, Jl. Terusan Ryacudu Jati Agung, Lampung Selatan \\ ${ }^{1}$ Email : ferri.22116130@student.itera..ac.id
}

DOI : 10.35472/jppk.v1i2.603

\begin{abstract}
Public space is an urban element that facilitates society interaction, communication and describes the quality of urban space. The public space affects the quality of social, economic and environmental, so that a quality public space is needed. Parks as public spaces in Tanggamus Regency are not evenly distributed because they are available in 3 sub-districts, namely Taman Kota Ir. Soekarno, Rest Area Taman Gisting and Rest Area Pugung showed that the provision of public space had not met the distribution and quantity aspects. The Gisting Park Rest Area is located in Gisting Urban which acts as a public space, so it is necessary to identify its quality. In addition, the declining quality of facilities and various other problems affect its quality. This study aims to determine the visitor's perception of the quality of the Gisting Park Rest Area as a public space. This study uses quantitative research methods with descriptive statistical analysis techniques and likert scale. Based on the results of the study, visitors' perceptions of the quality of the Rest Area Taman Gisting as a public space are sufficient to meet the needs of visitors, sufficient to protect the rights of visitors, and sufficient to provide meaning for visitors.
\end{abstract}

Keywords: Quality, Public Space, Perception

\section{A. PENDAHULUAN}

Ruang publik merupakan elemen perkotaan yang memiliki peranan penting sebagai pusat interaksi dan komunikasi bagi masyarakat baik secara formal maupun informal, individu maupun kelompok (Pratomo et al, 2019). Ruang publik sebagai elemen perkotaan dengan karakter tersendiri yang memiliki fungsi interaksi sosial bagi aktivitas masyarakat, kegiatan ekonomi rakyat dan apresiasi terhadap budaya (Darmawan, 2007). Kualitas ruang publik mempengaruhi kualitas manusia, membangun ruang publik yang berkualitas sama artinya membangun manusia yang berkualitas (Detik, 2015).

Ruang publik yang berkualitas merupakan ruang publik yang responsive, democratic, dan meaningfull (Carr et al, 1995). Konteks ruang publik yang berkualitas meliputi pemezznuhan terhadap kebutuhan (to support to needs), melindungi hak-hak pengguna (to protect the rights), dan memiliki makna (meaningful) (Prihastoto, 2003). Sehingga, pemenuhan aspek kualitas penyediaan ruang publik menjadi penting setelah pemenuhan aspek distribusi dan kuantitas ruang publik.

Penyediaan ruang publik memunculkan berbagai persepsi. Persepsi merupakan proses mengorganisir informasi yang diserap indera, guna menyadari dan memahami sekeliling kita (Shaleh, 2009). Pengunjung merupakan orang yang melakukan perjalanan, bukan tempat tinggalnya, kurang dari 12 bulan, dan bertujuan bukanlah terlibat kegiatan untuk mencari nafkah, pendapatan, atau penghidupan (Nurhidayah, 2017). Oleh karena itu, persepsi pengunjung berupa penilaian terhadap kualitas ruang publik. 
Penyediaan taman sebagai ruang publik di Kabupaten Tanggamus belum terdistribusi merata, karena hanya tersedia di 3 kecamatan yaitu Taman Kota Ir. Soekarno (Kecamatan Kota Agung Pusat), Rest Area Taman Gisting (Kecamatan Gisting) dan Rest Area Pugung (Kecamatan Pugung). Penyediaan ruang publik belum memenuhi aspek kuantitas dan distribusi sehingga ruang publik tersebut harus melayani kecamatan sekitarnya. Salah satunya Rest Area Taman Gisting yang melayani kecamatan sekitarnya yaitu Kecamatan Kota Agung Timur, Kecamatan Sumberejo, Kecamatan Ulubelu dan Kecamatan Pulau Panggung.

Rest Area Taman Gisting berada di Perkotaan Gisting, merupakan salah satu pusat perdagangan dan jasa di Kabupaten Tanggamus sebagai tempat beristirahat pengendara dan tempat rekreasi. Rest Area Taman Gisting berupaya meminimalisir minimnya penyediaan ruang publik aspek distribusi dan kuantitas, sehingga perlu diidentifikasi persepsi pengunjung terhadap kualitasnya. Selain itu, penyediaan fasilitas yang mulai menurun kualitasnya dan berbagai permasalahan lain turut mempengaruhi kualitas Rest Area Taman Gisting sebagai ruang publik.

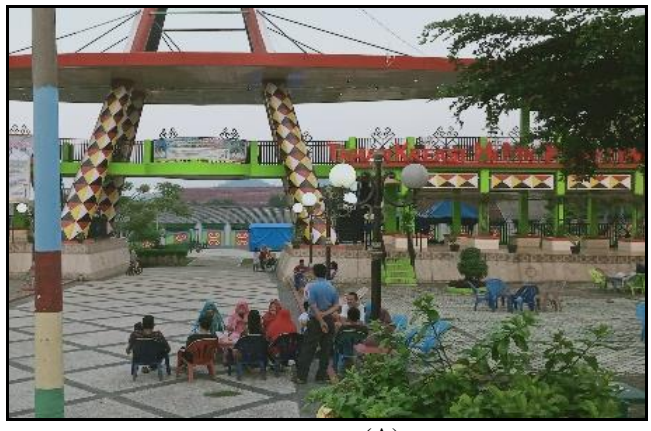

(A)

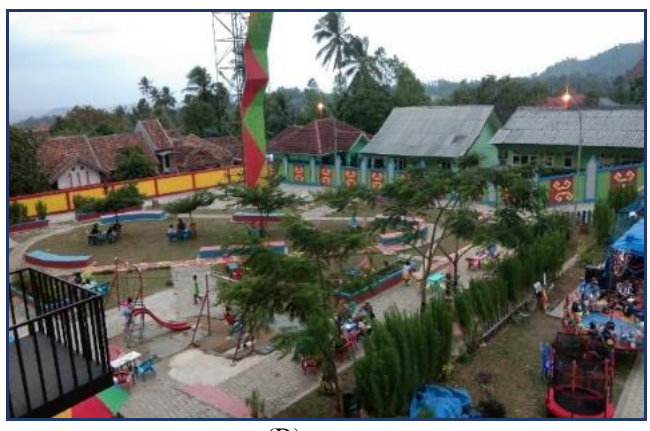

(B)

Sumber: Peneliti, 2020

Gambar 1. Rest Area Taman Gisting

(A) Aktivitas keluarga dan kerabat yang di Rest Area Taman Gisting.

(B) Aktivitas bermain anak seperti ayunan, jungkat-jungkit komedi putar, mandi bola dll.

Kualitas Rest Area Taman Gisting merupakan elemen penting sebagai daya tarik yang berpengaruh terhadap pengunjung. Perlu adanya upaya mengidentikasi kualitas responsibility, democraticity, dan meaningfully Rest Area Taman Gisting melalui persepsi pengunjung karena pengunjung merupakan subjek yang merasakan dampak langsung kualitas ruang publik. Oleh karena itu, penelitian ini bertujuan untuk mengetahui persepsi pengunjung terhadap kualitas Rest Area Taman Gisting sebagai ruang publik.

\section{B. METODE PENELITIAN}

Penelitian ini memiliki ruang lingkup temporal pada Agustus hingga Desember 2020 dan ruang lingkup spasial yaitu Rest Area Taman Gisting yang merupakan ruang publik yang berlokasi di Kecamatan Gisting, Kabupaten Tanggamus, Lampung. Berikut merupakan site plan Rest Area Taman Gisting. 


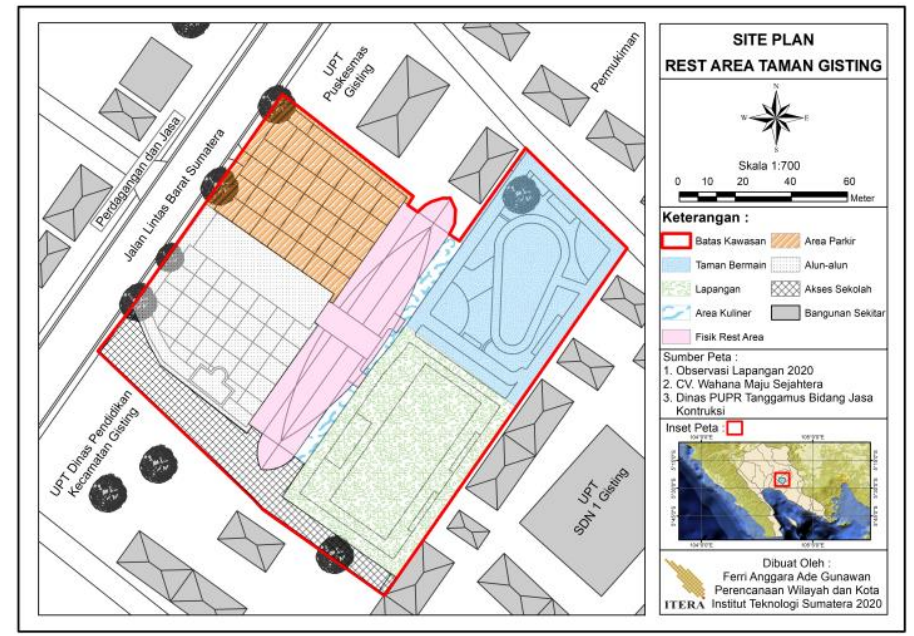

Sumber : Digitasi Peneliti, 2020

Gambar 2. Site Plan Rest Area Taman Gisting

Berdasarkan gambar 2, Rest Area Taman Gisting terbagi menjadi 6 zonasi aktivitas yaitu area alun-alun, area parkir, area bangunan rest area, area olahraga, area bermain anak dan area kuliner. Rest Area Taman Gisting merupakan ruang publik pertama di Kecamatan Gisting sebagai wilayah yang direncanakan menjadi kawasan perkotaan dengan konsep agropolitan dan sebagai pusat penyangga Industri Maritim Tanggamus (Bappeda Tanggamus, 2018).

Penelitian ini menggunakan pendekatan deduktif, variabel dan indikator kualitas ruang publik berdasarkan teori-teori dasar. Teori Carr et al (1995) tentang aspek pembentuk kualitas ruang publik yaitu responsive (mampu memenuhi kebutuhan penggunanya), democratic (mampu melindungi hak-hak pengguna ruang publik) dan meaningsfull (mampu memberikan suatu hubungan yang kuat antara ruang publik), menjadi teori dasar penelitian yang diperkuat sintesa literatur dari teori lainnya.

Penelitian ini menggunakan teknik pengumpulan data primer dan data sekunder. Data primer penelitian ini menggunakan kuesioner kepada responden yaitu sampel pengunjung dan observasi guna memperoleh informasi melalui pengamatan langsung serta sebagai uji konsistensi kuesioner. Data sekunder penelitian ini menggunakan kajian literatur berupa dasar teori, penelitian terdahulu, dokumen RTRW, shapefile Tanggamus, serta master plan Rest Area Taman Gisting dan survei instansi mengumpulan data sekunder dari Dinas Pekerjaan Umum dan Perumahan Rakyat Kabupaten Tanggamus.

Penelitian ini menggunakan teknik sampling yaitu non probability sampling menggunakan accidental sampling. Accidental sampling menemukan sampel pengunjung yang kebetulan dijumpai peneliti dan dipandang cocok sebagai sumber data (Sugiyono, 2017). Adapun kriteria responden yaitu minimal 2 kali berkunjung dan berusia minimal 15 tahun, asumsi responden tersebut telah memahami hal yang baik dan buruk (Khoiriyanah, 2016). Penentuan jumlah sampel menggunakan rumus lemeshow karena tidak diketahui jumlah pasti pengunjung dan dihasilkan adalah 96,44 yang dibulatkan menjadi minimal 100 sampel pengunjung.

Penelitian ini menggunakan metode penelitian kuantitatif menggunakan teknik analisis statistik deskriptif dan metode skoring skala likert. Analisis statistik deskriptif 
untuk analisis data dengan mendeskripsikan data persepsi pengunjung. Metode skoring dalam penelitian ini berupa penilaian terhadap kualitas ruang publik menggunakan skala likert yang terbagi menjadi 5 kategori kualitas yaitu sangat tidak baik, tidak baik, cukup baik, baik dan sangat baik. Adapun kategorisasi kualitas berdasarkan perhitungan kelas interval. Tahapan analisis dimulai dari persepsi terhadap responsibility, persepsi terhadap democraticity dan persepsi terhadap meaningsfully yang kemudian hasilnya dikalkulasikan hingga diperoleh nilai kualitas Rest Area Taman Gisting.

\section{HASIL DAN PEMBAHASAN}

\section{Persepsi Pengunjung Terhadap Kualitas Responsibility}

Persepsi pengunjung berupaya mengidentifikasi kualitas responsibility Rest Area Taman Gisting (kualitas dalam memenuhi kebutuhan pengunjung) yang memberikan penilaian melalui persepsi terhadap aspek kenyamanan, aspek relaksasi, aspek keterlibatan secara pasif, dan aspek keterlibatan secara aktif.

a) Aspek Kenyamanan

Aspek kenyamanan diukur berdasarkan persepsi 100 responden terhadap ketersediaan dan kondisi fasilitas peneduh, tempat duduk, pedagang, pedestrian, penerangan, vegetasi (tanaman), persampahan, sanitasi, telekomunikasi dan perkerasan/lantai.

Sumber: Analisis Peneliti, 2021

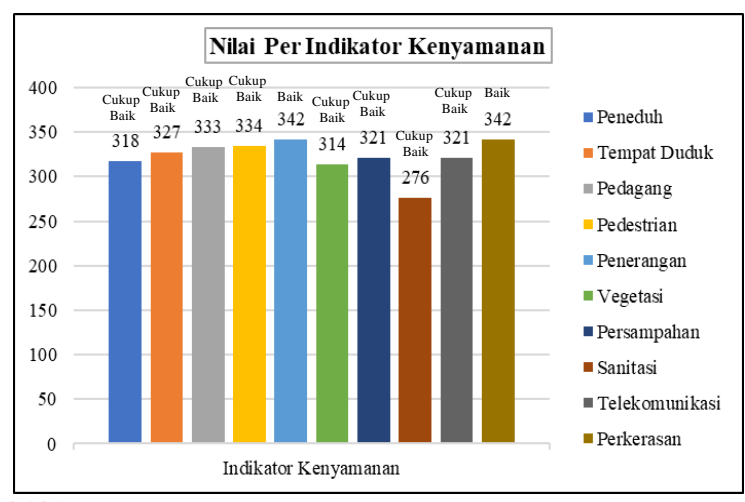

Gambar 3. Diagram Nilai Per Indikator Kenyamanan

Kenyamanan merupakan rasa nyaman untuk tinggal atau beraktivitas di suatu kawasan atau obyek (Darmawan, 2005). Aspek kenyamanan Rest Area Taman Gisting berdasarkan persepsi pengunjung termasuk dalam kategori cukup baik, menunjukkan bahwa Rest Area Taman Gisting cukup baik dalam memberikan kenyamanan untuk tinggal dan beraktivitas bagi pengunjung melalui penyediaan fasilitas dan pelayanan yang ada. Akan tetapi, perlu adanya upaya peningkatan kenyamanan, khususnya peningkatan kualitas persampahan dan kualitas sanitasi guna menciptakan kualitas lingkungan yang lebih nyaman.

b) Aspek Relaksasi

Aspek relaksasi (bersantai) diukur berdasarkan persepsi 100 responden terhadap aktivitas relaksasi, kebisingan, keamanan dan pelayanan darurat. 


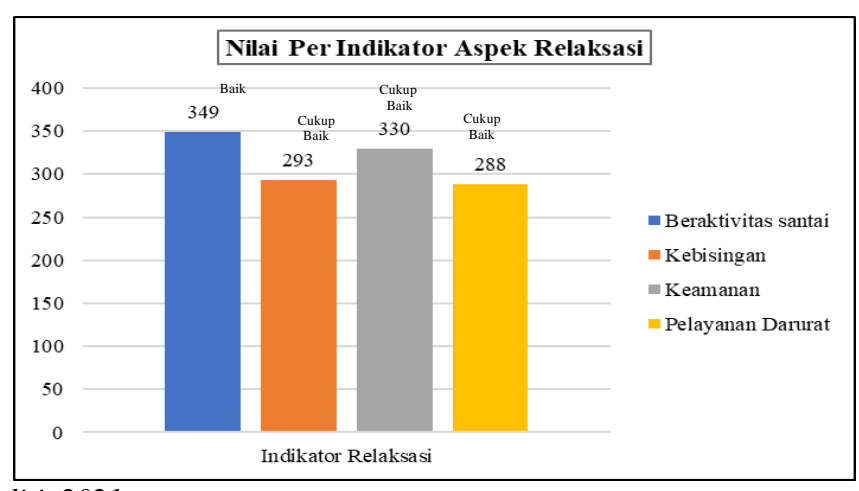

Sumber : Analisis Peneliti, 2021

Gambar 4. Diagram Nilai Per Indikator Relaksasi

Menurut Carr et al (1995), relaksasi merupakan kondisi yang ingin diperoleh pengunjung dalam beraktivitas di taman dengan berbagai tema didalamnya, sehingga pengunjung bisa menikmati setiap aktivitasnya. Aspek relaksasi Rest Area Taman Gisting berdasarkan persepsi pengunjung termasuk dalam kategori cukup baik, menunjukkan bahwa Rest Area Taman Gisting cukup baik dalam menciptakan suasana bersantai bagi pengunjung meskipun adanya kebisingan akibat lokasi yang tepat berada disisi jalan raya yaitu Jalan Lintas Barat Sumatera yang cukup padat kendaraan yang melintas. Pengunjung pun merasa keamanan yang cukup baik dan pelayanan darurat yang tidak jauh dari lokasi ruang publik cukup mengakomodasi kebutuhan pengunjung.

c) Aspek Keterlibatan Pasif

Aspek keterlibatan pasif di Rest Area Taman Gisting diukur berdasarkan persepsi 100 responden terhadap kualitas dalam mengamati berbagai aktivitas, mengamati arsitektur bangunan/lingkungan dan menikmati pemandangan alam.

Sumber : Analisis Peneliti, 2021

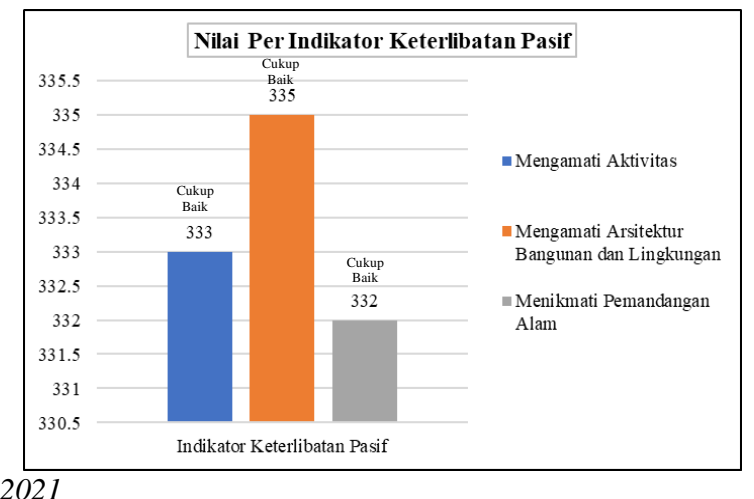

Gambar 5. Diagram Nilai Per Indikator Keterlibatan Pasif

Keterlibatan secara pasif merupakan keterlibatan pengunjung dalam suatu ruang publik dalam hal mengamati, memandang maupun berdialog dengan alam (Carr et al, 1995). Aspek keterlibatan secara pasif di Rest Area Taman Gisting berdasarkan persepsi pengunjung termasuk dalam kategori cukup baik, menunjukkan bahwa pengunjung 
merasa cukup baik ketika terlibat secara pasif baik saat mengamati aktivitas, mengamati arsitektur lingkungan dan pemandangan alam sekitar Rest Area Taman Gisting.

\section{d) Aspek Keterlibatan Aktif}

Aspek keterlibatan secara aktif di Rest Area Taman Gisting diukur berdasarkan persepsi 100 responden terhadap kualitas saat melintasi taman, saat berkomunikasi, saat perayaan/festival, saat beraktivitas di ruang anak-anak dan saat beraktivitas di ruang remaja atau dewasa.

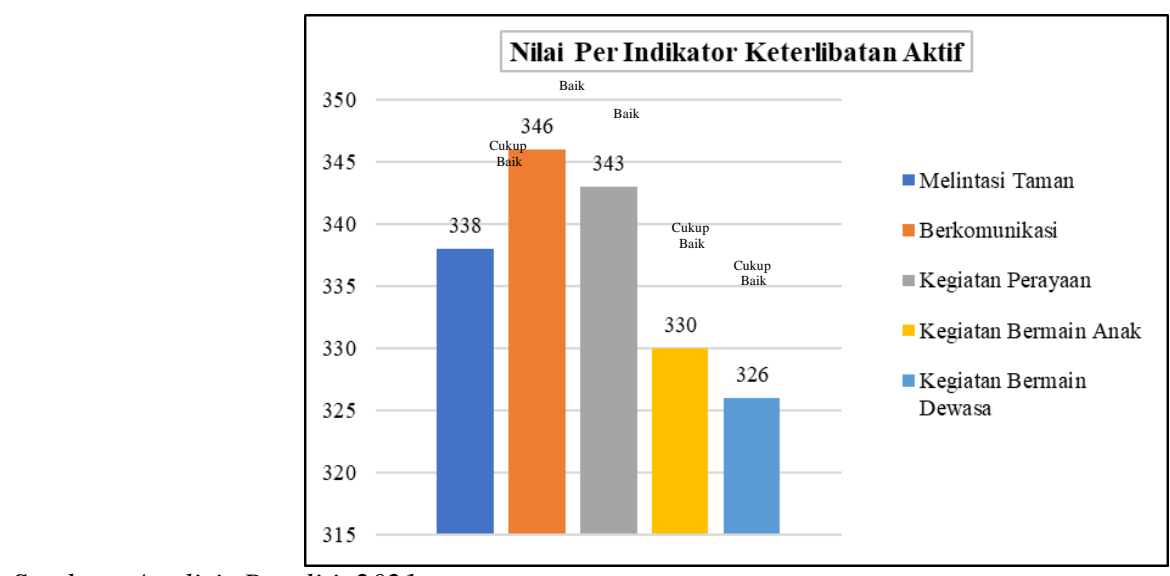

Sumber : Analisis Peneliti, 2021

Gambar 6. Diagram Nilai Per Indikator Keterlibatan Aktif

Keterlibatan secara aktif (active engagement) merupakan keterlibatan pengunjung dalam ruang publik melalui berbagai kegiatan aktif lebih dari sekedar mengamati (Carr et al, 1995). Aspek keterlibatan secara pasif di Rest Area Taman Gisting berdasarkan persepsi pengunjung termasuk dalam kategori cukup baik, menunjukkan bahwa pengunjung merasa cukup baik ketika melakukan berbagai kegiatan aktif melintasi taman berkomunikasi, perayaan, bermain anak dan dewasa di Rest Area Taman Gisting. Berdasarkan pemaparan diatas, berikut merupakan tabel nilai persepsi pengunjung terhadap kualitas responsibility Rest Area Taman Gisting sebagai ruang publik.

Tabel 1. Persepsi Terhadap Kualitas Responsibility

\begin{tabular}{|c|c|c|c|}
\hline No & Variabel Responsibility & Skor & Kualitas \\
\hline 1 & Kenyamanan & 3328 & Cukup Baik \\
\hline 2 & Relaksasi & 1260 & Cukup Baik \\
\hline 3 & Keterlibatan Pasif & 1000 & Cukup Baik \\
\hline 4 & Keterlibatan Aktif & 1683 & Cukup Baik \\
\hline & Total Skor & 7171 & Cukup Baik \\
\hline
\end{tabular}

Berdasarkan tabel 1, diketahui bahwa aspek kenyamanan, aspek bersantai, aspek keterlibatan pasif dan aspek keterlibatan aktif termasuk dalam kategori cukup baik. Kemudian kalkulasi nilai aspek-aspek tersebut diperoleh nilai total sebesar 1717 berdasarkan kategorisasi kelas interval responsibility berada dalam kategori cukup baik. Sehingga diketahui bahwa persepsi pengunjung terhadap kualitas responsibility Rest 
Area Taman Gisting sebagai ruang publik adalah cukup baik dalam memenuhi kebutuhan pengunjung baik dari segi penyediaan fasilitas dan pelayanan bagi pengunjung.

\section{Persepsi Pengunjung Terhadap Kualitas Democraticity}

Persepsi pengunjung berupaya mengidentifikasi kualitas democraticity Rest Area Taman Gisting (kualitas dalam melindungi hak pengguna dalam mengakses ruang publik) yang memberikan penilaian melalui persepsi terhadap aspek aksesibilitas dan aspek kebebasan beraktivitas.

a) Aspek Aksesibilitas

Aspek aksesibilitas Rest Area Taman Gisting diukur berdasarkan persepsi 100 responden terhadap akses fisik, akses visual, pencapaian semua golongan, signage atau penanda dan akses parkir.

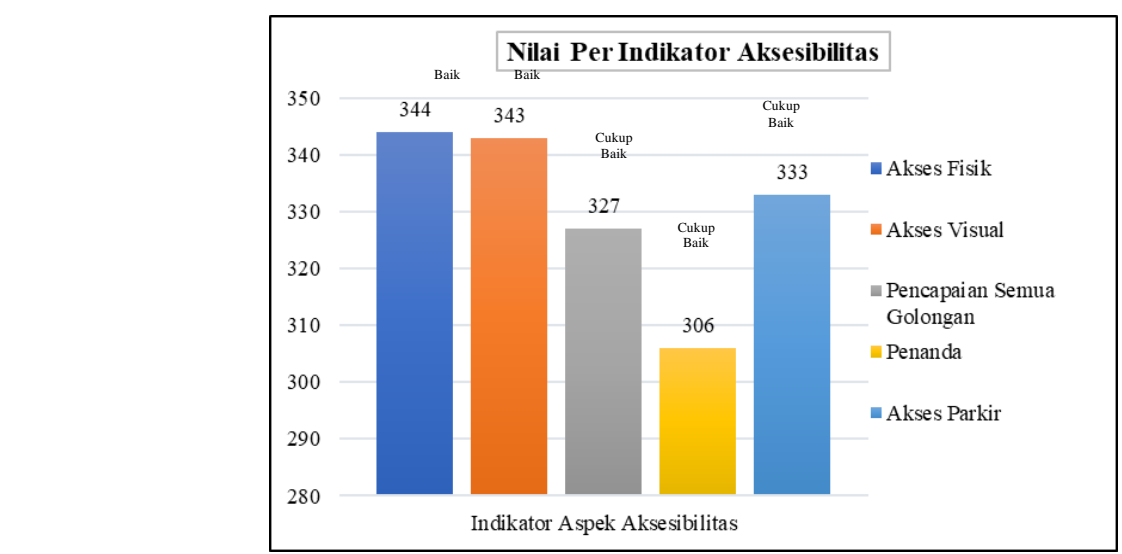

Sumber : Analisis Peneliti, 2021

Gambar 7. Diagram Nilai Per Indikator Aksesibilitas

Menurut Carr et al (1992) dalam Prastika (2019), aksesibilitas ruang publik hendaknya bersifat demokratis, dapat dinikmati semua golongan dan mudah diakses secara fisik maupun visual. Aspek aksesibilitas Rest Area Taman Gisting berdasarkan persepsi pengunjung termasuk dalam kategori cukup baik, menunjukkan bahwa Rest Area Taman Gisting cukup baik untuk diakses oleh semua golongan, akan tetapi perlu adanya penambahan fasilitas ramah penyandang disabilitas agar mereka mudah mengakses Rest Area Taman Gisting secara menyeluruh.

\section{b) Aspek Kebebasan Beraktivitas}

Aspek kebebasan beraktivitas di Rest Area Taman Gisting diukur berdasarkan persepsi 100 responden terhadap bebas beraktivitas, zonasi ruang publik, pembatas aktivitas dan klaim ruang. 


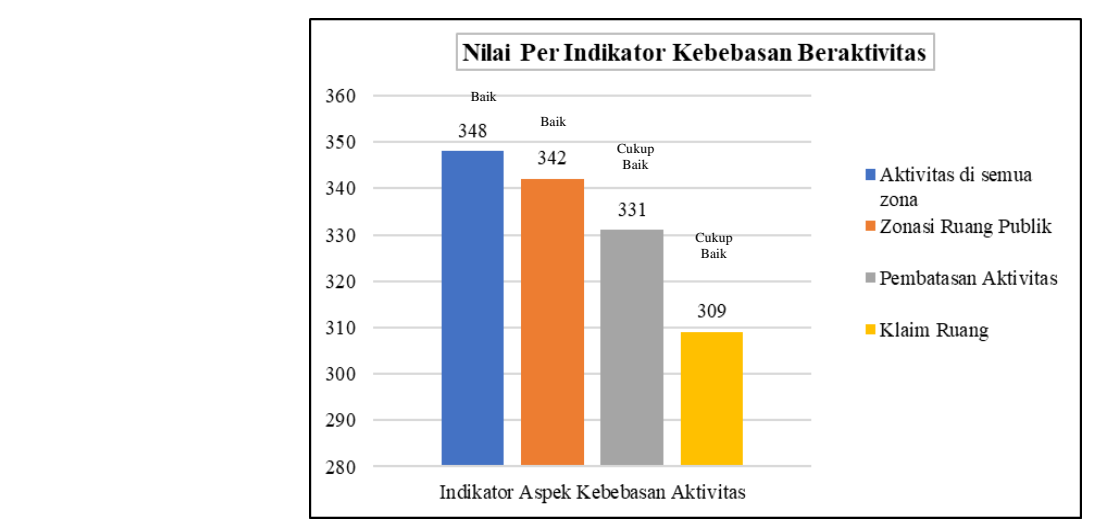

Sumber : Analisis Peneliti, 2021

Gambar 8. Diagram Nilai Per Indikator Kebebasan Beraktivitas

Kebebasan bergerak atau kebebasan aktivitas (freedom of action) merupakan kebebasan bagi pengguna ruang publik dalam beraktivitas kesemua bagian ruang publik (Carr et al, 1995). Aspek kebebasan beraktivitas Rest Area Taman Gisting berdasarkan persepsi pengunjung termasuk dalam kategori cukup baik, menunjukkan bahwa Rest Area Taman Gisting cukup baik untuk memberikan kebebasan bagi pengunjung untuk melakukan berbagai aktivitas, kebebasan mengakses semua zona bahkan cukup baik di klaim oleh pengunjung untuk aktivitas pribadi dan adanya pembatasan aktivitas karena pandemi Covid-19 dinilai cukup baik demi pencegahan persebaran Covid-19 di Kabupaten Tanggamus. Berdasarkan pemaparan diatas, berikut merupakan tabel nilai persepsi pengunjung terhadap kualitas democraticity Rest Area Taman Gisting sebagai ruang publik.

Tabel 2. Persepsi Terhadap Kualitas Democraticity

\begin{tabular}{cccc}
\hline No & Variabel Democraticity & Skor & Kualitas \\
\hline 1 & Aksesibilitas & 1653 & Cukup Baik \\
2 & Kebebasan Beraktivitas & 1330 & Cukup Baik \\
\hline & Total Skor & $\mathbf{2 9 8 3}$ & Cukup Baik \\
\hline
\end{tabular}

Berdasarkan tabel.2 diketahui bahwa aspek aksesibilitas dan aspek kebebasan beraktivitas di Rest Area Taman Gisting memiliki kategori cukup baik. kemudian nilai kedua aspek pembentuk kualitas democraticity tersebut dikalkusikan sehingga diperoleh nilai sebesar 2983 berdasarkan kategorisasi kelas interval democraticity berada dalam kategori cukup baik. Sehingga diketahui bahwa persepsi pengunjung terhadap kualitas democraticity Rest Area Taman Gisting sebagai ruang publik adalah cukup baik dalam melindungi hak-hak pengunjung dalam mengakses Rest Area Taman Gisting.

\section{Persepsi Pengunjung Terhadap Kualitas Meaningsfully}

Persepsi pengunjung berupaya mengidentifikasi kualitas meanigsfully Rest Area Taman Gisting (kualitas dalam memberikan kebermaknaan bagi pengunjung) yang memberikan penilaian melalui persepsi terhadap aspek legibility, aspek relevansi, aspek 
hubungan individu, hubungan kelompok dan hubungan dengan aspek biologis dan psikologis.

a) Aspek Legibility (Kemudahan dimengerti)

Aspek legibility Rest Area Taman Gisting diukur berdasarkan persepsi 100

responden terhadap penghubung antara zona, wadah aktivitas sosial, batas-batas area dan landmark ruang publik.

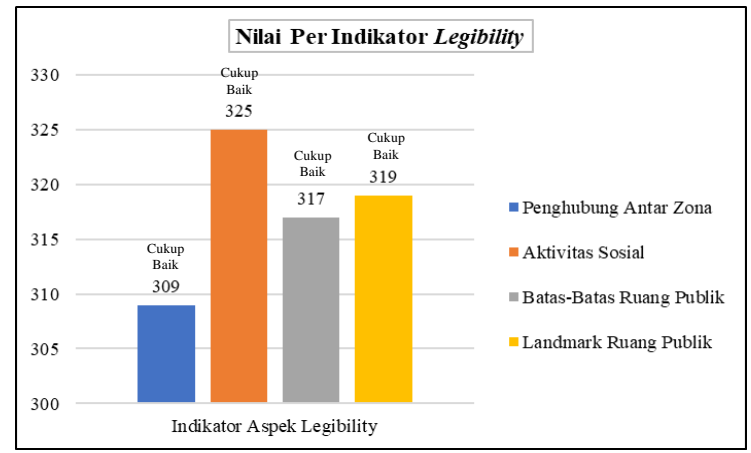

Sumber : Analisis Peneliti, 2021

Gambar 9. Diagram Nilai Per Indikator Legibility

Ruang publik yang legibility merupakan ruang publik yang mudah dipahami dan dimengerti penggunanya (Carr et al, 1995), sehingga pengguna ruang publik mengerti kondisi baik fisik maupun non fisik ruang publik yang mereka kunjungi. Aspek legibility Rest Area Taman Gisting berdasarkan persepsi pengunjung termasuk dalam kategori cukup baik, menunjukkan bahwa Rest Area Taman Gisting cukup baik atau cukup mudah untuk dipahami dan dimengerti baik dari segi fisik seperti penghubung antara zona, pembagian zona aktivitas, batas-batas area dan landmark maupun segi non fisik berupa berbagai aktivitas sosial di Rest Area Taman Gisting.

b) Aspek Relevansi

Aspek relevansi Rest Area Taman Gisting diukur berdasarkan persepsi 100 responden terhadap kesesuaian dengan norma masyarakat dan kesesuaian desain maupun manajemen di ruang publik.

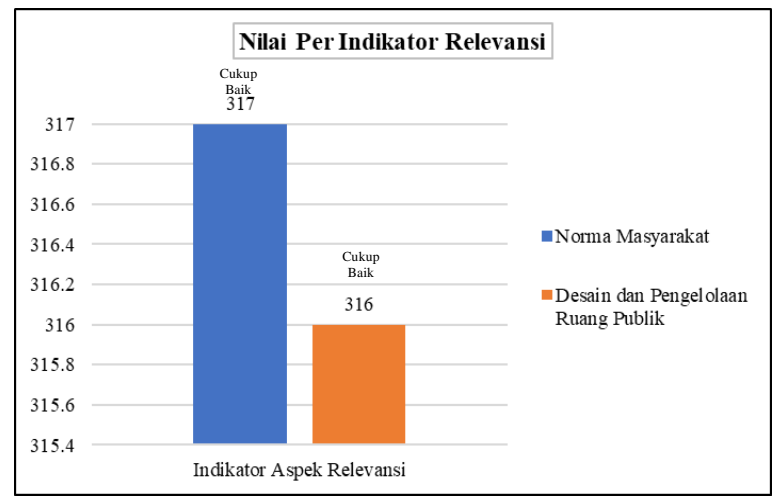

Sumber : Analisis Peneliti, 2021

Gambar 10. Diagram Nilai Per Indikator Kebebasan Relevansi 
Ruang publik yang bersifat relevan (sesuai) merupakan suatu ruang publik yang memiliki relevansi atau kesesuaian dengan karakteristik masyakat setempat (Carr et al, 1995). Aspek relevansi (kesesuaian) Rest Area Taman Gisting berdasarkan persepsi pengunjung termasuk dalam kategori cukup baik, menunjukkan bahwa Rest Area Taman Gisting cukup baik atau cukup sesuai norma masyarakat karena tidak didapati adanya keluhan berupa pelanggaran norma, desain bangunan yang cukup sesuai dengan budaya masyarakat Lampung dan pengelolaan yang cukup sesuai dengan persepsi pengunjung.

c) Aspek Hubungan Individu

Aspek hubungan individu di Rest Area Taman Gisting diukur berdasarkan persepsi 100 responden terhadap nilai-nilai pesan/sejarah dan event/perayaan di ruang publik.

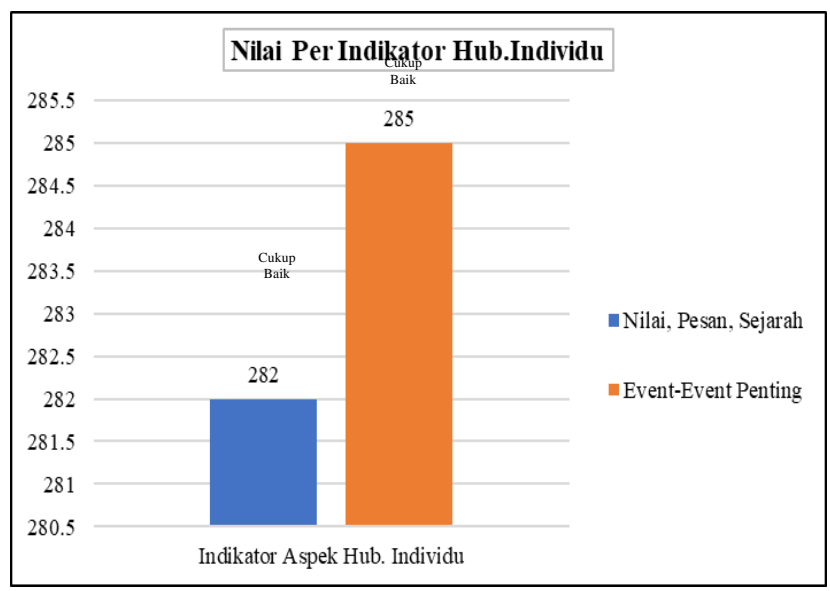

Sumber : Analisis Peneliti, 2021

Gambar 11. Diagram Nilai Per Indikator Kebebasan Hub.Individu

Ruang publik hendaknya memberikan suatu kebermaknaaan ketika pengguna ruang publik dalam suatu hubungan individu, sehingga secara individu pengguna memahami kondisi di ruang publik (Carr et al, 1995). Aspek hubungan individu di Rest Area Taman Gisting berdasarkan persepsi pengunjung termasuk dalam kategori cukup baik, menunjukkan bahwa Rest Area Taman Gisting cukup baik dalam mengakomodasi pemahaman pengunjung sebagai suatu individu terhadap nilai atau pesan dan event-event penting di Rest Area Taman Gisting.

\section{d) Aspek Hubungan Kelompok}

Aspek hubungan kelompok di Rest Area Taman Gisting diukur berdasarkan persepsi 100 responden terhadap aktivitas sosial komunitas, aktivitas kelompok olahraga dan aktivitas kelompok kesenian. 


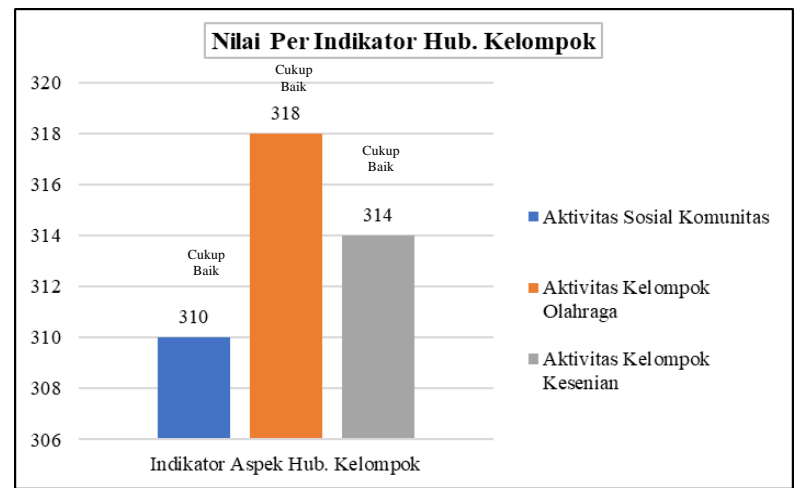

Sumber : Analisis Peneliti, 2021

Gambar 12. Diagram Nilai Per Indikator Hubungan Kelompok

Ruang publik hendaknya memiliki kemampuan dalam mengakomodasi pengguna dalam melakukan aktivitas kelompok, sehingga pengguna ruang publik memahami makna setiap aktivitas berkelompok yang berlangsung (Carr et al, 1995). Aspek hubungan kelompok di Rest Area Taman Gisting berdasarkan persepsi pengunjung termasuk dalam kategori cukup baik, menunjukkan bahwa Rest Area Taman Gisting cukup baik dalam mengakomodasi kebutuhan pengunjung untuk beraktivitas secara berkelompok maupun dalam memahami aktivitas kelompok yang ada di Rest Area Taman Gisting baik aktivitas komunitas, olahraga dan kesenian.

e) Hubungan dengan Aspek Bio dan Psikologis

Ruang publik hendaknya memiliki hubungan dengan aspek biologis dan psikologi dalam hal ini diukur berdasarkan persepsi 100 responden terhadap hubungan ruang dengan elemen alam dan hubungan ruang utama dengan ruang sekitarnya.

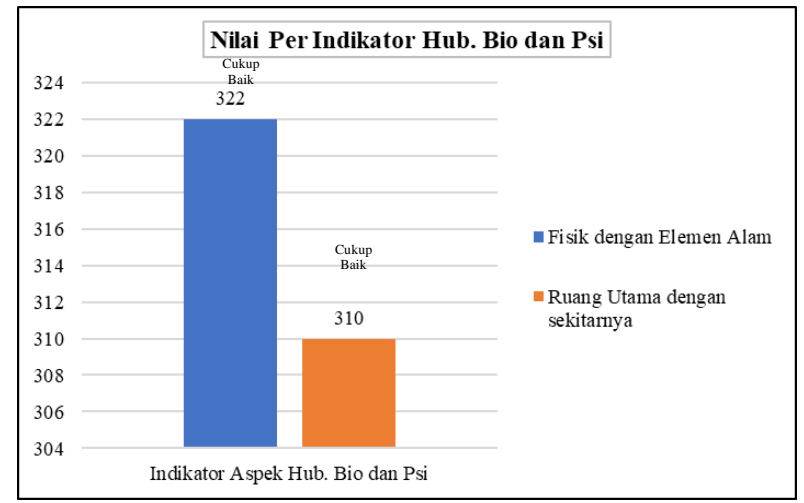

Sumber : Analisis Peneliti, 2021

Gambar 13. Diagram Nilai Per Indikator Hubungan Bio dan Psi

Ruang publik yang meaningfully hendaknya memiliki suatu keterhubungan penataan ruang dengan aspek lingkungan hidup biologis dan psikologis orientasi ruang. Aspek hubungan dengan aspek biologis dan psikologis di Rest Area Taman Gisting berdasarkan persepsi pengunjung termasuk dalam kategori cukup baik, menunjukkan bahwa Rest Area Taman Gisting cukup baik dalam penataan elemen alam dan orientasi bangunan Rest Area sebagai ruang orientasi atau ruang utama di Rest Area Taman Gisting. Berdasarkan 
pemaparan diatas, berikut merupakan tabel nilai persepsi pengunjung terhadap kualitas meaningsfully Rest Area Taman Gisting sebagai ruang publik.

Tabel 3. Persepsi Terhadap Kualitas Meaningsfully

\begin{tabular}{|c|c|c|c|}
\hline No & Variabel Meaningsfully & Skor & Kualitas \\
\hline 1 & Kemudahan dimengerti & 1270 & Cukup Baik \\
\hline 2 & Relevansi & 633 & Cukup Baik \\
\hline 3 & Hub. Individu & 567 & Cukup Baik \\
\hline 4 & Hub. Kelompok & 942 & Cukup Baik \\
\hline 5 & Hub dengan Bio \& Psi & 632 & Cukup Baik \\
\hline & $\begin{array}{l}\text { Total Skor } \\
\end{array}$ & 4044 & Cukup Baik \\
\hline
\end{tabular}

Berdasarkan tabel 3, diketahui bahwa secara keseluruhan aspek pembentuk kualitas meaningsfully yang terdiri dari aspek legibility, aspek relevansi, aspek hubungan individu, aspek hubungan kelompok dan aspek hubungan dengan biologi dan psikologi termasuk dalam kategori cukup baik. Kemudian nilai aspek-aspek tersebut dikalkulasikan sehingga diperoleh nilai sebesar $\mathbf{4 0 4 4}$ berdasarkan kategorisasi kelas interval meaningsfully berada dalam kategori cukup baik. Sehingga diketahui bahwa persepsi pengunjung terhadap kualitas meaningsfully Rest Area Taman Gisting sebagai ruang publik adalah cukup baik dalam memberikan suatu kesan atau makna bagi pengunjung Rest Area Taman Gisting.

\section{Interpretasi Persepsi Pengunjung Terhadap Kualitas Rest Area Taman Gisting}

Pengukuran kualitas Rest Area Taman Gisting sebagai ruang publik berdasarkan persepsi pengunjung berupaya mengidentifikasi kualitas responsive, democratic dan meaningful. Berdasarkan persepsi pengunjung kalkulasi kualitas Rest Area Taman Gisting sebagai berikut.

Tabel 4. Persepsi Terhadap Kualitas Ruang Publik

\begin{tabular}{|c|c|c|c|}
\hline No & Aspek Kualitas & Skor Persepsi & Kualitas \\
\hline 1 & Responsibility & 7.171 & Cukup Baik \\
\hline 2 & Democraticity & 2.983 & Cukup Baik \\
\hline 3 & Meaningsfully & 4.044 & Cukup Baik \\
\hline & Total Skor & 14.198 & Cukup Baik \\
\hline
\end{tabular}

Berdasarkan tabel 4, diketahui bahwa kualitas responsibility, kualitas democraticity, dan kualitas meaningsfully bernilai cukup baik, kemudian ketiga aspek pembentuk kualitas ruang publik tersebut dikalkulasikan memperoleh nilai $\mathbf{1 4 . 1 9 8}$ yang berdasarkan kategorisasi kelas interval kualitas Rest Area Taman Gisting berada dalam kategori cukup baik. Ruang publik yang berkualitas merupakan ruang publik yang memiliki kemampuan dalam mengakomodasi aktivitas publik agar menjadi responsive terhadap kebutuhan (needs) bagi penggunanya, bersifat demokratis (democraticity) terhadap perlindungan hak-hak (rights) penggunanya, serta memiliki makna (meanings) yang lebih berarti terkait nilai-nilai sosial budaya setempat. 
Hal tersebut menunjukkan bahwa persepsi pengunjung kualitas Rest Area Taman Gisting ditinjau dari tingkat responsibility, democraticity, dan meaningsfully bernilai cukup baik dalam menenuhi kebutuhan pengunjung, cukup baik dalam melindungi hakhak pengunjung, dan cukup baik dalam memberikan makna bagi pengunjung Rest Area Taman Gisting. Terindentifikasi kualitas Rest Area Taman Gisting dalam kategori cukup baik menunjukkan perlu adanya upaya guna meningkatkan kualitasnya sebagai ruang publik. Kualitas cukup baik menjadikan Rest Area Taman Gisting sebagai salah satu gambaran kualitas ruang perkotaan Gisting dalam mendukung aktivitas masyarakat.

\section{KESIMPULAN}

Berdasarkan analisis penelitian ini, teridentifikasi persepsi pengunjung terhadap kualitas responsibility Rest Area Taman Gisting sebagai ruang publik melalui perhitungan total nilai termasuk dalam kualitas cukup baik, menunjukan bahwa Rest Area Taman Gisting cukup baik dalam mengakomodasi kebutuhan (needs) bagi penggunanya melalui penyediaan fasilitas dan jasa pelayanan. Kemudian identifikasi persepsi pengunjung terhadap kualitas democraticity Rest Area Taman Gisting sebagai ruang publik melalui perhitungan total nilai termasuk dalam kualitas cukup baik, menunjukan bahwa Rest Area Taman Gisting cukup baik dalam memberikan perlindungan terhadap hak-hak pengunjung dalam mengakses ruang-ruang yang tersedia.

Identifikasi persepsi pengunjung terhadap kualitas meaningfully Rest Area Taman Gisting sebagai ruang publik melalui perhitungan total nilai dalam kualitas cukup baik, menunjukkan bahwa Rest Area Taman Gisting cukup baik dalam dalam memberikan nilai, pesan sejarah dan kebermaknaan bagi pengunjung yang beraktivitas di Rest Area Taman Gisting. Oleh karena itu, berdasarkan persepsi pengunjung terhadap kualitas responsibility, democraticity dan meaningsfully dapat disimpulkan bahwa persepsi pengunjung terhadap kualitas Rest Area Taman Gisting sebagai ruang publik adalah cukup baik dalam memenuhi kebutuhan pengunjung, melindung hak-hak pengunjung dan dalam memberikan suatu nilai atau kebermaknaan bagi pengunjung. Oleh karena itu, perlu adanya komitmen pemerintah bersama dengan stakeholders untuk meningkatkan kualitas responsibility, democraticity dan meaningsfully Rest Area Taman Gisting sebagai ruang publik.

Menurut Darmawan (2007), keberadaan ruang publik dalam hal ini yaitu taman yang berpengaruh terhadap lingkungan perkotaan yang menggambarkan peningkatan kualitas ruang kota salah satunya dapat dilakukan dengan mengembangkan taman sebagai ruang publik baik dari segi kuantitas maupun kualitas. Persepsi pengunjung terhadap kualitas Rest Area Taman Gisting sebagai ruang publik termasuk dalam kategori cukup baik, kondisi tersebut menunjukkan bahwa berdasarkan persepsi pengunjung kualitas Rest Area Taman Gisting cukup baik dalam menggambarkan kualitas ruang perkotaan Gisting melalui penyediaan ruang publik sekaligus landmark kawasan perkotaaan Gisting.

Identifikasi kualitas ruang publik berdasarkan persepsi pengunjung perlu diadakan secara berkala sebagai bentuk evaluasi selain inspeksi dari pemerintah selaku penanggungjawab penyedia ruang publik. Kolaborasi dari keduanya guna memelihara dan meningkatkan kualitas karena secara kuantitas luas kawasan Rest Area Taman Gisting yang sudah maksimal sehingga harus mampu memanfaatkan ruang yang terbatas 
melalui penyediaan sarana prasarana, peraturan dan pelayanan sesuai dengan kebutuhan masyarakat

\section{DAFTAR PUSTAKA}

[1] Bappeda Tanggamus. (2018). Arahan Kebijakan dan Prioritas Pembangunan Kabupaten Tanggamus 2018. Disampaikan pada Musrenbang Tanggamus 2018. Tanggamus.

[2] Carr, S., Francis, M., Rivlin, L. G., \& Stone, A. M. (1995). Public Space. UK: Cambridge University Press.

[3] Darmawan, E. (2005). Ruang Publik dan Kualitas Ruang Kota. Seminar Nasional PESAT 2005 (pp. A35-A43). Jakarta: Proceeding. Seminar Nasional PESAT 2005.

[4] Darmawan, E. (2007). "Peranan ruang Publik dalam Perancangan Kota (Urban Design)". Upacara Penerimaan Guru besar dalam Ilmu Arsitektur Fakultas Teknik Universitas Diponegoro. Semarang: Badan Penerbit Universitas Diponegoro.

[5] Detik. (2015, Bulan Oktober Hari Selasa). Dipetik Bulan Agustus Tanggal 20, 2020 dari https://news.detik.com/berita/d-3037079/jokowi-kualitas-ruang-publik-tentukankualitas-masyarakat-kota.

[6] Khoiriyanah, A. (2016). Identifikasi Persepsi Pengunjung Terhadap Fasilitas dan Fungsi Taman Cibeunying dan Taman Monumen Perjuangan Rakyat. Tugas Akhir tidak diterbitkan, Program Studi Perencanaan Wilayah dan Kota Sekolah Arsitektur, Perencanaan dan Pengembangan Kebijakan (SAPPK) Institut Teknologi Bandung, Bandung.

[7] Nurhidayah. (2017). "Karakteristik Pengunjung Pada Objek Wisata Danau Cipogas Kabupaten Rokan Hulu". Skripsi tidak diterbitkan, Program Studi Usaha Perjalanan Wisata, Jurusan Ilmu Administrasi, Fakultas Ilmu Sosial dan Ilmu Politik Universitas Riau, Riau.

[8] Pemerintah Daerah Kabupaten Tanggamus . (2005). Peraturan Daerah Kabupaten Tanggamus Nomor 5 Tahun 2005 Tentang Pembentukan Kecamatan Kotaagungbarat, Kota Agung Timur, Gisting, Gunung Alip, Ambarawa, Banyumas. Tanggamus.

[9] Prastika, M. (2019). "Persepsi Masyarakat Terhadap Revitalisasi Pusat Kegiatan Olahraga dan Budaya (PKOR) Way Halim Sebagai Ruang Publik". Tugas Akhir tidak diterbitkan, Program Studi Perencanaan Wilayah dan Kota, Jurusan Teknologi Infrastruktur dan Kewilayahan Institut Teknologi Sumatera, Lampung Selatan.

[10] Pratomo, A., Soedwiwahjono, \& Miladan, N. (2019). "Kualitas Taman Kota Sebagai Ruang Publik di Kota Surakarta Berdasarkan Persepsi dan Prefensi Pengguna". Jurnal Desa-Kota Vol.1, No.1, Hal.84-95.

[11] Prihastoto. (2003). "Kajian Kualitas Ruang Publik pada Alun-Alun Kota Purworejo". Tesis tidak diterbitkan, Magister Teknik Arsitektur Program

[12] Shaleh, A. R. (2009). Psikologi Suatu Pengantar Dalam Perspektif Islam. Jakarta: Kencana.

[13] Sugiyono. (2017). Metode Penelitian Kuantitatif, Kualitatif dan R\&D. Bandung: ALFABETA.cv. 